\title{
Emilio, un entrañable profesor, investigador y amigo
}

Un día, alguien llamó a la puerta de mi despacho, era Emilio. Un joven en busca de futuro. Tenía la mente llena de ideas. Un futuro profesor de traducción con formación interdisciplinar en filosofía, filología románica y traducción e interpretación.

Completó su formación en varios países como Bélgica, Francia y Estados Unidos. Todo este esfuerzo lo encaminó a apostar por ser profesor en Málaga en la que llegaría a ser Catedrático, superando a su maestro.

Fue un intelectual con ganas de aportar ideas como se puede comprobar en su bibliografía. Fue profesor visitante y dio numerosas conferencias en muchos países, no solo en los países ya mencionados, sino también en Suiza, México, Reino Unido, Italia, Portugal, Dinamarca, Marruecos...

Era incansable y lo recuerdo como una gran persona. No quiero citar los distintos lugares específicos en los que estuvo, sino subrayar una trayectoria digna y llena de vitalidad.

Con estas sencillas y pocas palabras, solo he querido recordar a una entrañable persona que pude conocer con muchas ganas de vivir. Sin embargo, se nos fue y a menudo, los recuerdos traen lágrimas de amistad.

Querido Emilio, siempre estarás en mis recuerdos más profundos. 